Bangladesh J. Plant Taxon. 23(1): 59-63, 2016 (June)

(C) 2016 Bangladesh Association of Plant Taxonomists

\title{
GLOCHIDION TALAKONENSE SP. NOV. (PHYLLANTHACEAE) FROM SESHACHALAM BIOSPHERE RESERVE, ANDHRA PRADESH, INDIA
}

\author{
M. Sankara RaO ${ }^{1}$, J. SwamY ${ }^{2}$, S. Nagaraju ${ }^{2}$, S.B. Padal ${ }^{3}$, M. Tarakeswara Naidu ${ }^{3}$, \\ K. ChANDRAMOHAN ${ }^{2}$ AND T. ThULASIAH ${ }^{4}$ \\ Botanical Survey of India, Sikkim Himalayan Regional Centre, Gangtok, Sikkim- 737103, India
}

Keywords: Glochidion talakonense; New species; Phyllanthaceae; Andhra Pradesh; India.

\begin{abstract}
Glochidion talakonense M. Sankara Rao, J. Swamy, S. Nagaraju, S.B. Padal, M. Tarakeswara Naidu, K. Chandramohan \& T. Thulasiah, a new species of Phyllanthaceae from Talakona hills, Seshachalam Biosphere Reserve, Andhra Pradesh, India, is described and illustrated. It is allied to G. karnaticum Chakrab. \& M. Gangop., but differs from the latter by stamens, ovary, style and fruit characters.
\end{abstract}

\section{Introduction}

The Seshachalam hills, spread in Chittoor and Kadapa districts of Andhra Pradesh, were declared as Biosphere Reserve by Government of India in 2010. The Reserve lies between the latitudes of $13^{\circ} 38^{\prime \prime}$ and $13^{\circ} 55^{\prime \prime} \mathrm{N}$ and the longitudes of $79^{\circ} 07^{\prime \prime}$ and $79^{\circ} 24^{\prime \prime} \mathrm{E}$ with an area of $\mathrm{c}$. $4755.99 \mathrm{sq} . \mathrm{km}$. The vegetation of the reserve is chiefly Southern dry mixed deciduous forests, dry deciduous scrub, dry savannah, Red sander forests and Hardwickia forests (Champion and Seth, 1968). A total of 1756 species of flowering plants belonging to 176 families are estimated to occur in this area (Sudhakar, 2012). The hill ranges vary in elevation from 400 to $1370 \mathrm{~m}$ with an average altitude of $700 \mathrm{~m}$ above sea level.

The genus Glochidion J.R. Forst \& G. Forst. is represented by c. 320 species distributed in tropical Asia to Northern Australia and Polynesia, a few species in Madagascar and tropical America (Chakrabarty and Gangopadhyay, 1995, 2012; Balakrishnan and Chakrabarty, 2007). In India, the genus is represented by c. 22 species and 8 varieties, of which 3 species and one variety are reported from Andhra Pradesh (Babu, 1997; Chakrabraty and Gangopadhyay, 1995, 2012). Recently, one new species was described from the Seshachalam Hills (Rasingam et al., 2014). While exploring the Talakona area of Seshachalam Biosphere Reserve, the authors collected an interesting species of Glochidion, which on critical observations showed conspicuous differences from all other known species of the genus. The same is therefore described and illustrated here as a new species Glochidion talakonense sp. nov. and compared with the allied G. karnaticum Chakrab. \& M. Gangop.

Glochidion talakonense M. Sankara Rao, J. Swamy, S. Nagaraju, S.B. Padal, M. Tarakeswara Naidu, K. Chandramohan \& T. Thulasiah sp. nov.

(Figs 1 \& 2).

Diagnosis: Glochidion talakonense is allied to G. karnaticum Chakrab. \& M. Gangop., but differ in the asymmetric-rounded leaf-base, 5 stamens, 6-locular ovary and capsules and the longer columnar style, inflexed at apex (Table 1).

\footnotetext{
${ }^{1}$ Corresponding author. Email: mudadlas@gmail.com

${ }^{2}$ Botanical Survey of India, Deccan Regional Centre, Hyderabad - 500048, Telangana, India.

${ }^{3}$ Department of Botany, Andhra University, Visakhapatnam, Andhra Pradesh, India.

${ }^{4}$ S.L.V.Garden \& Landscape developers, Tirupati, Andhra Pradesh, India.
} 
Type: India. Andhra Pradesh, Chittoor Dist.,Talakona hills $\left(13^{0} 48^{\prime} 43.7^{\prime \prime} \mathrm{N} \& 79^{0} 13^{\prime} 05.5^{\prime \prime} \mathrm{E}\right)$, 852 m, 16 Apr 2014, M. Sankara Rao \& Party, 4465 (Holotype: CAL; Isotypes: BSID); ibid.,9 Sep 2014, M. Sankara Rao \& Party 5503 (Paratypes: BSID).

Trees, up to $7 \mathrm{~m}$ high; branches spreading; branchlets terete, puberulous when young, glabrescent at maturity, greenish-yellow. Leaves oblong to oblong-elliptic, 4.0-12.5 x 2.5-6.2 $\mathrm{cm}$, asymmetric-rounded at base, entire, acuminate at apex, thinly coriaceous, glabrous, green above, glaucous beneath; lateral veins 7-8 pairs, prominent on both sides; petioles $4-5$ x c. $2 \mathrm{~mm}$, glabrous; stipules subulate, 1-2 mm long, puberulous. Inflorescences axillary, sessile, fascicled, 8many-flowered, unisexual or bisexual. Male flowers: up to 18 in each fascicle, c. $2.0 \times 1.8 \mathrm{~mm}$, brownish-pink; pedicels filiform, up to $4 \mathrm{~mm}$ long; tepals $3+3$, free, unequal, spreading and recurved, puberulous outside, glabrous inside; outer ones $1.8 \times 1.3 \mathrm{~mm}$, ovate, acute at apex; inner ones 1.8-2.0 x c. $1 \mathrm{~mm}$, elliptic-oblong, rounded at apex; stamens 5 ; anthers connate into an oblong mass, c. $0.8 \times 0.6 \mathrm{~mm}$, connectives c. $0.3 \times 0.3 \mathrm{~mm}$; anther thecae linear, longitudinally dehiscent. Female flowers: many in each fascicle, $4-5 \times 4.5-4.7 \mathrm{~mm}$, greenish with purple tinge; pedicels $2-4 \mathrm{~mm}$ long; tepals $3+3$, free or occasionally shortly connate at base, unequal, tawnypuberulous on both surfaces; outer ones 1.8-2.2 x 1.6-1.8 mm, ovate, acute at apex; inner ones 1.4$2.0 \times 0.8-1.2 \mathrm{~mm}$, oblong, rounded or acute at apex; ovary subglobose, c. $2.3 \times 2.6 \mathrm{~mm}$, glabrous or puberulous, 6-locular, locules biovulate; styles columnar, inflexed at apex, c. $2.3 \times 0.9 \mathrm{~mm}$; apical lobes 6 , linear or triangular, tawny-puberulous. Fruits capsular, 6-7 x 8-9 mm, shallowly lobed, slightly depressed, glabrous or puberulous. Seeds 12, glabrous.

Phenology: Flowering \& Fruiting: April - September.

Etymology: The species is named after the type locality, "Talakona", a famous water fall in Seshachalam Biosphere Reserve in Chittoor district of Andhra Pradesh.

Habitat: Along waterfalls in moist deciduous forests at about $852 \mathrm{~m}$ elevation growing in association with Allophylus cobbe, Syzygium alternifolium and Phoenix loureiroi.

Table 1. Morphological comparison of Glochidion talakonense sp. nov. and its allied G. karnaticum.

\begin{tabular}{|c|c|c|}
\hline Characters & Glochidion talakonense sp. nov. & Glochidion karnaticum \\
\hline Leaves & Asymmetric-rounded at base & Acute at base \\
\hline Petioles & $4-5 \times$ c. $2.2 \mathrm{~mm}$ & $2-3 \times 1.0-1.5 \mathrm{~mm}$ \\
\hline Male pedicels & Up to $4 \mathrm{~mm}$ long & 7-10 mm long \\
\hline Male tepals & $\begin{array}{l}\text { Unequal, outer ones ovate, } 2.3-2.6 \times 1.5-1.7 \\
\mathrm{~mm} \text {; inner ones elliptic-oblong, } 1.8-2.0 \times \\
0.9-1.0 \mathrm{~mm}\end{array}$ & $\begin{array}{l}\text { Equal, oblong, elliptic-ovate, } 1-2 \times \\
0.5-1.0 \mathrm{~mm}\end{array}$ \\
\hline Anthers & 5 & 3 \\
\hline Female pedicels & 2-4 mm long & c. $2 \mathrm{~mm}$ long. \\
\hline Female tepals & $\begin{array}{l}\text { Unequal, outer ones ovate, } 1.8-2.2 \times 1.6-1.85 \\
\mathrm{~mm} \text {; inner ones oblong, } 1.4-2.0 \times 0.8-1.2 \\
\mathrm{~mm}\end{array}$ & Equal, oblong, $1.0-1.5 \times$ c. $0.5 \mathrm{~mm}$ \\
\hline Ovary & 6-locular, $2.0-2.6 \mathrm{~mm}$ in diameter & 4-locular, c. $1 \mathrm{~mm}$ in diameter \\
\hline Style & Columnar, inflexed at apex, c. $2.3 \times 0.9 \mathrm{~mm}$ & Columnar, c. $1 \times 0.4 \mathrm{~mm}$ \\
\hline Fruits & $6-7 \times 8-9 \mathrm{~mm}, 6$-locular & $2-3 \times 4-5 \mathrm{~mm}, 4$-locular \\
\hline
\end{tabular}




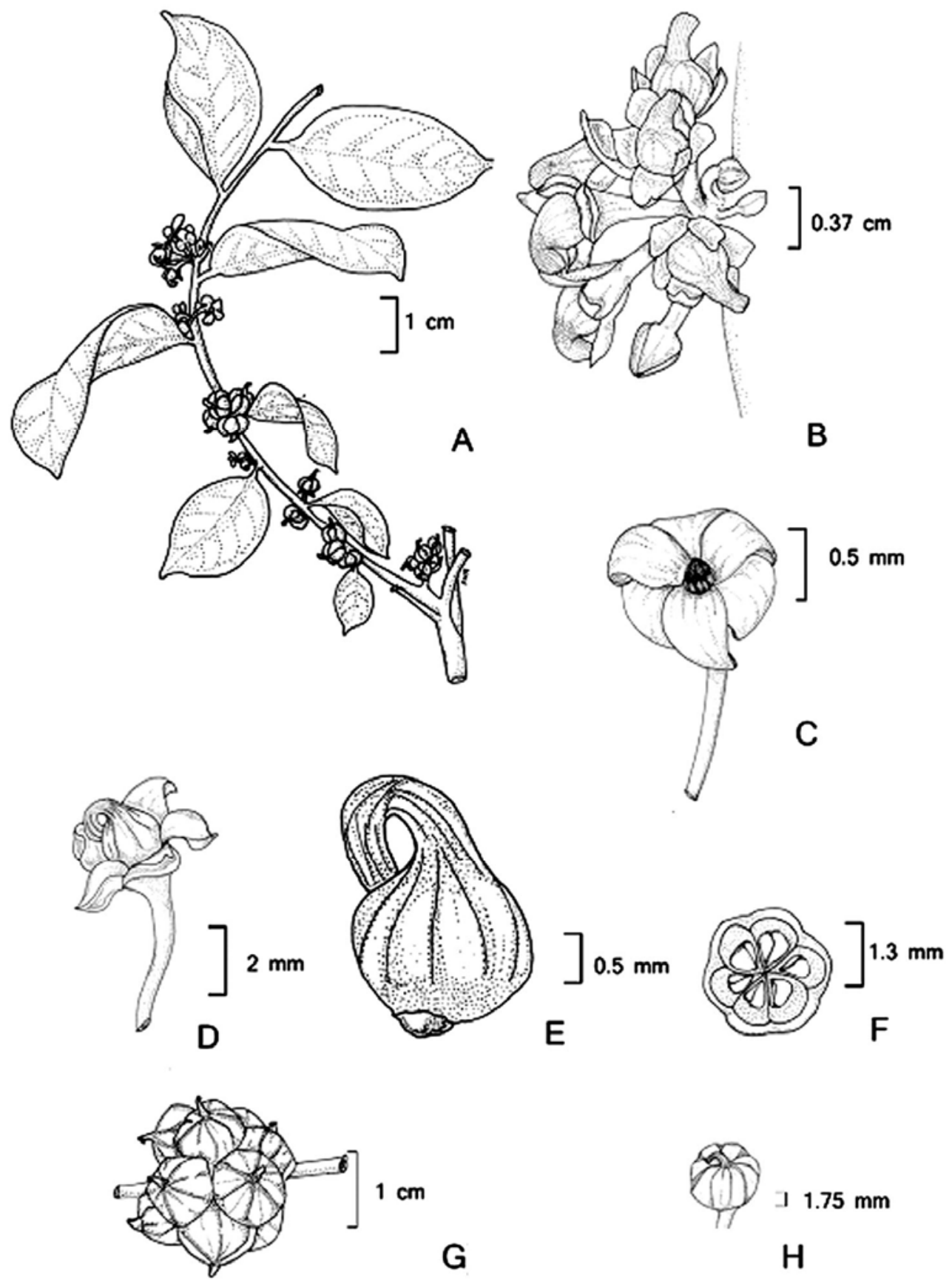

Fig. 1. Glochidion talakonense, sp. nov. A. Flowering branch; B. Inflorescence; C. Male flower; D. Female flower; E. Gynoecium; F. T.S. of ovary; G-H. Fruits. 

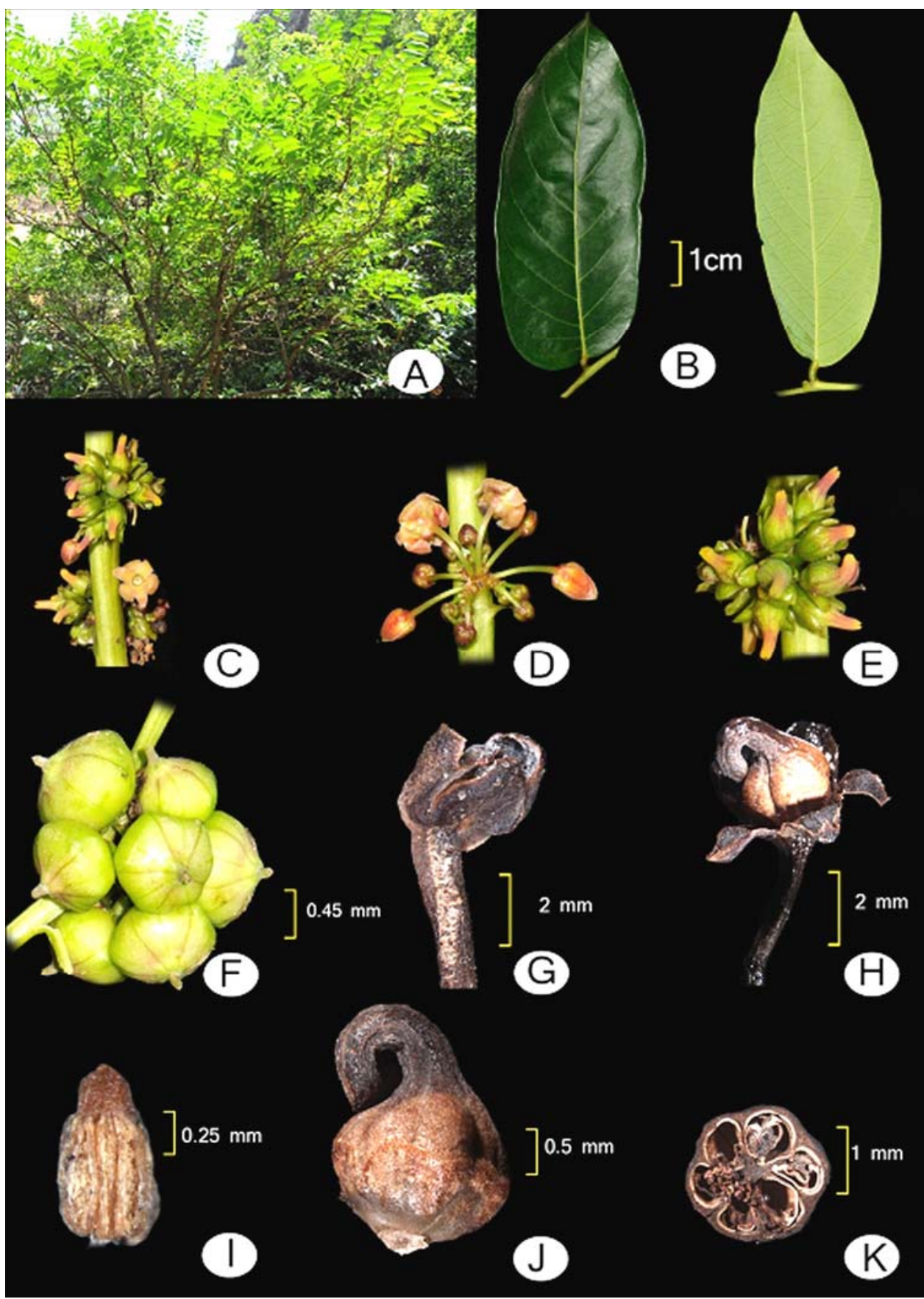

Fig. 2. Glochidion talakonense, sp. nov. A. Habit; B. Adaxial and abaxial view of leaves; C. Inflorescence (mixed); D. Male inflorescence; E. Female inflorescence; F. Fruits; G. Male flower; H. Female flower; I. Androecium; J. Gynoecium; K. T. S. of ovary. (from type specimen) 
Conservation status: Glochidion talakonense is a local endemic and so far known only from its type locality with nearly five [Criteria D] mature individuals. As it is known from a single location [Criteria B(a)], the Extent of Occurrence, EOO [Criteria B1] and Area of Occupancy, $\mathrm{AOO}$ [Criteria B2] is calculated as $4 \mathrm{~km}^{2}$ by taking the minimum grid size of $2 \mathrm{~km}^{2}$. The quality of habitat is declining [Criteria $\mathrm{B}(\mathrm{b}$-iii)] due to climate change and high anthropogenic pressure through tourism. In view of the above, by applying IUCN Red Listing criteria and guidelines (IUCN, 2012) the threat perspective of this species has been assessed as "Critically Endangered" [CR Blab (iii) $+2 \mathrm{ab}(\mathrm{iii})$; D]. Habitat management and propagation studies are suggested conservation measures for this species.

\section{Acknowledgements}

The authors are thankful to the Director, Botanical Survey of India, Kolkata and Scientist Incharge, Botanical Survey of India, Deccan Regional Centre, Hyderabad for providing facilities and to the Forest Department officials, Government of Andhra Pradesh for permission and logistic support during field surveys. Thanks are due to Dr. D.K. Agrawala, Scientist In-charge, Botanical Survey of India, Sikkim Himalayan Regional Centre, Gangtok for encouragements and valuable suggestions and to Dr. T. Chakrabarty, ex Scientist, Botanical Survey of India for suggesting the alliance.

\section{References}

Babu, S.P.1997. Euphorbiaceae In: Pullaiah, T. and Ali Moulali, D. (Eds), Flora of Andhra Pradesh (India) 2: 836-890. Scientific Publishers, Jodhpur, India.

Balakrishnan, N.P. and Chakrabarty, T. 2007. The Family Euphorbiaceae in India - A synopsis of its Profile, Taxonomy and Bibliography. Bishen Singh, Mahendrapal Singh, Dehradun, India, pp. 1-500.

Chakrabarty, T. and Gangopadhyay, M. 1995. The genus Glochidion (Euphorbiaceae) in the Indian Subcontinent. J. Econ. Taxon. Bot 19: 173-234.

Chakrabarty, T. and Gangopadhyay, M. 2012. Glochidion. In Balakrishan, N.P, Chakrabarty, T., Sanjappa, M., Lakshminarasimhan, P. and Singh, P. (Eds), Flora of India, 23:87-511 Botanical Survey of India, Kolkata.

Champion, H.G. and Seth, S.K. 1968. A revised survey of the forest types of India. Manager of publications, New Delhi, pp. 1-404.

IUCN. 2012. IUCN Red List Categories and Criteria: Version 3.1. Second edition. Gland, Switzerland and Cambridge, UK: IUCN. iv + 32 pp.

Rasingam, L., Chorghe, A.R., Prasanna, P.V. and Sankara Rao, M. 2014. Glochidion tirupathiense (Phyllanthaceae) - A new species from Seshachalam Biosphere Reserve of Andhra Pradesh, India. Taiwania 59(1): 9-12.

Sudhakar, G. 2012. Seshachalam Biosphere Reserve - Deccan South, India. In: Palni, L.M.S. and Rawal, R.S. (Eds), Compendium on Indian Biosphere Reserve, Progression during two decades of Conservation. Ministry of Environment \& Forests, New Delhi. pp. 178-183. 